\title{
Illustrations
}

\section{Black-and-White Figures}

I.1 Advertisement for Swisstex Girdle, 1955

1.2 Vintage postcard 4

I. 3 Etching of a woman composed of household tools by Giovanni Battista Braccelli in Bizzari di Varie Figure, I624 6

1.1 "Pygmalion Embracing the Image" miniature in the style of Robinet Testard in Guillaume de Lorris and Jean de Meun, Le Roman de la Rose, late fifteenth century Io

1.2 Louis-Jean-François Lagrenée I, Pygmalion and His Statue, I777 I2

1.3 Honoré Daumier, Pygmalion, lithograph from his Histoire ancienne series, December I8, I842

1.4 An I888 photograph of Julia Marlowe as Galatea in a production of W. S. Gilbert's play Pygmalion and Galatea

1.5 Amelia being admired by Arthur Moore and Dr. Phillips in E. E. Kellett's story “The Lady Automaton," Pearson's Magazine, June r9or 2I

1.6 Margot Kidder as the flower girl Eliza Doolittle and the transformed Eliza in a 1983 television production of George Bernard Shaw's play Pygmalion

1.7 Phonographic doll manufactured at Thomas Edison's West Orange, New Jersey, factory, I890 28

2.1 "Gavrochinette" manufactured by Phalibois in Paris, ca. 1900 
2.2 Gavrochinette, who wore men's clothes and a man's hat jauntily on her head, was a real-life popular entertainer in Parisian clubs like the Moulin Rouge

2.3 Mademoiselle Catherina, from an original painting in Vauxhall Garden, etching/engraving by Robert Sayer, ca. 1750

2.4 Casanova dancing with the beautiful doll Rosalba in Fellini's Casanova, 1976

2.5 Nineteenth-century female automaton

2.6 The Rights of Women, automaton by Renou, ca. 1900

2.7 Nineteenth-century stereograph

2.8 Automaton of a female bicycliste by Vichy

2.9 The female Snake Charmer automaton by Roullet \& Decamps, I890

2.10 Chinese female tea server automaton by Léopold Lambert, ca. $1900 \quad 48$

2.11 Autoperipateikos walking doll, 1870 , invented in 1862 by Enoch Rice Morrison

3.1 Olympia being wound up in Leo Délibe’s ballet Coppélia

3.2 The Tales of Hoffmann (195I) with Moira Shearer as Olympia and Robert Rounseville as Hoffmann

3.3 German actress Ossi Oswalda as Ossi in Ernst Lubitsch's 1919 silent film Die Puppe (The Doll)

3.4 Maria with electrodes on her head being subjected to electricity and soon to be transformed into her evil double in Fritz Lang's film Metropolis

3.5 The "good" Maria, played by German actress Brigitte Helm, offers comfort to the children of the city in Metropolis

3.6 The evil, android version of Maria, also played by Brigitte Helm, in Metropolis

3.7 The Monster (Boris Karloff) and the Monster's Mate (Elsa Lanchester) in James Whale's 1935 film Bride of Frankenstein, loosely based on Mary Shelley's novel Frankenstein (I8I8, I83I)

3.8 Vogue magazine cover illustration, November 24, 1930

3.9 Marlene Dietrich as Lola Lola in Josef von Sternberg's 1930 film Der blaue Engel (The Blue Angel) 
3.10 Russian ballerina Alexandra Danilova with a doll of herself, in Massiné's Boutique Fantastique

3.11 Plate from Hans Bellmer’s book La Poupée (The Doll), 1936

3.12 Linocut illustration from the essay "Memories of a Doll Theme" in Hans Bellmer's La Poupée, 1936

3.13 Berlin Dada artist Hanna Höch's photocollage Das schöne Mädchen (The Beautiful Girl), 1920

3.14 The Robots dance

4.1 Ava Gardner plays the voluptuous Venus in One Touch of Venus (1948) 9I

4.2 Professor Henry Higgins (Rex Harrison) dancing with the elegant Eliza (Audrey Hepburn) in My Fair Lady (1964)

4.3 An American woman war worker resisting the embrace of a male robot in a 1940 s cartoon

4.4 Marsha in the 1960 Twilight Zone television series episode "The After Hours"

4.5 The 1963 "Living Doll" episode of The Twilight Zone

4.6 Robert Cummings and Julie Newmar, the statuesque, beautiful robot in My Living Doll, 1964-1965

4.7 Dee Hartford as the silvery, accomplished female android Verda in the 1966 episode "The Android Machine" of Lost in Space

4.8 Fembot with her face exposed in the 1976 "Kill Oscar" episode of Bionic Woman

4.9 Wire "cage" crinolines under voluminous dresses helped women lighten the load of multiple petticoats, I850

4.10 The glamorous and pensive robot Rachael (Sean Young) in Ridley Scott's 1982 iconic film Blade Runner

4.11 Pris (Daryl Hannah), a "pleasure robot," in the film Blade Runner

4.12 The kindly robot grandmother comforts Agatha in Rod Serling's television series The Twilight Zone in the 1962 episode "I Sing the Body Electric"

4.13 Lisa (Kelly LeBrock), a beautiful mail-order robot, and one of her young creators in the 1985 Hollywood film Weird Science

5.1 The professor's niece Penelope (Patricia Roc) impersonating a robot in the 1949 British film comedy The Perfect Woman 
5.2 Walter (Matthew Broderick) introduces his beautiful, blond, newly transformed wife, Joanna (Nicole Kidman), in the 2004 remake of The Stepford Wives

5.3 Lars (Ryan Gosling) seated next to his doll Bianca in the film Lars and the Real Girl

6.1 Andrea Thomaz, professor of interactive computing and head of the Socially Intelligent Machines Lab at the Georgia Institute of Technology, with the lab's female research robot Curi, introduced in 2013

6.2 The "First Robot Super Model" HRP-4C 2009 (an acronym for Humanoid Robotics Project) designed by Japan's National Institute of Advanced Industrial Science and Technology Institute and introduced at Tokyo's Digital Content Expo in 2009

6.3 Still from Icelandic rock singer Björk's 1999 music video, All Is Full of Love

7.1 Heidi Kumao, Protest (2005)

7.2 Video still of American artist Joan Jonas in her performance video Organic Honey's Visual Telepathy, 1972

7.3 Cindy Sherman, Untitled \# 474, 2008

7.4 Laurie Simmons, photograph from her series of dollhouse images, $1976-1978$

7.5 Nancy Burson, Untitled (girl with doll's eyes)

7.6 Nancy Burson, Untitled (mannequin with real girl's mouth and eyes)

\section{Color Plates}

I Julie Wosk, Bag Lady, 1992

II Jean-Léon Gérôme, Pygmalion and Galatea, ca. I890

III Lady Musician, intricate clockwork automaton created by Pierre and Henri Jaquet-Droz, 1773

IV The Flower Vendor automaton by Vichy, ca. 1885

V Julie Wosk, Marlene, 1995

VI A male scientist with his white coat operates on a female robot, her exposed body parts lying on the table 
VII Glamorous, compliant robot women at the Simply Stepford Day Spa in the 2004 Hollywood remake of The Stepford Wives

VIII Postgraduate student Takahiro Takeda at Japan's Tohoku University dancing with a robot at a factory, Chino city, China

IX An ultrarealistic female robot made of silicone and electronics, Repliee QII, designed and developed by Professor Hiroshi Ishiguro, director of the Osaka University Intelligent Robotics Communications Laboratory in Japan

X Cynthia Breazeal, director, MIT Media Lab, Personal Robots Group, and the early robot Kismet developed by Breazeal at MIT 1993-2000

XI Aimee Mullins, from Howard Schatz's Athlete

XII Mariko Mori, Birth of a Star, 1995 
